RAPHISA.

Revista de Antropología y Filosofía de lo Sagrado Review of Anthropology and Philosophy of the Sacrum

ISSN: 2530-1233 Nº 4, Julio-Diciembre (2018) pp.: 61-70

\title{
THE BANQUET AS A FEAST OF RECONCILIATION
}

\section{EL BANQUETE COMO FIESTA DE RECONCILIACIÓN}

\author{
Xavier Escribano ${ }^{1}$ \\ Universitat Internacional de Catalunya(España)
}

\begin{abstract}
Using the guise of a simple supper of commemoration of the hundredth anniversary of the birth of a charismatic Protestant pastor, who had gathered around him a community of devoted disciples in a small village in Norway, Babette's Feast by Isak Dinesen shows us a banquet in which, through the food prepared with the eye of an artist, the senses are awakened for the first time to a kind of experience where what is corporal and what is spiritual cease to be at odds with each other. Thus, a reconciliation of a lost unity between the body and the soul, matter and spirit, is celebrated and achieved. From this first step, with which the fundamental internal fragmentation is overcome, the other levels of unity (unity with others, with the cosmos, and with God) occur in a chain sequence, so to speak. As in all religious situations, there occurs here the coming together of two orders that seem unreconciliable: the temporal and the eternal, the limited and the infinite, the profane and the sacred. The mediator between both orders is Babette, who takes on a genuine sacerdotal function. However, there is an unexpected inversion, and paradoxically what is profane and mundane comes to the rescue of what is spiritual and sacred.
\end{abstract}

Key words: BANQUET; RECONCILIATION; SACRED; PROFANE; BODY; SOUL

Resumen: Bajo la apariencia de una sencilla cena de conmemoración del centenario del nacimiento de un carismático pastor protestante, que había congregado en torno a sí una pequeña comunidad de devotos discípulos en una pequeña aldea de Noruega, El Festín de Babette de Isak Dinesen nos presenta un banquete en el que, a través de la materia elaborada artísticamente, los sentidos despiertan por primera vez a un tipo de experiencia donde lo corpóreo y lo espiritual dejan de estar reñidos. Así, se celebra y se consigue eficazmente la reconciliación de una unidad perdida entre el cuerpo y el alma, entre la materia y el espíritu. A partir de ese primer paso en el que se supera la fragmentación interna fundamental se suceden en cadena, por decirlo así, los otros niveles de unidad, también fragmentados y descompuestos, la unidad con los otros, con el cosmos, con Dios. Como en toda situación religiosa, se produce aquí el encuentro entre dos órdenes que parecen inconmensurables: el orden de lo temporal

[1] (xescriba@uic.es) Xavier Escribano (Badalona, 1970) es Doctor en Filosofía por la Universitat de Barcelona y profesor de Antropología Filosófica y Teoría del Conocimiento en la Universitat Internacional de Catalunya. Desde 2012 dirige Sarx, grupo de investigación interdisciplinar en el campo de la antropología de la corporalidad. Autor de la monografía Sujeto encarnado y expresión creadora. Una aproximación al pensamiento de Maurice Merleau-Ponty (2004), ha publicado diversos artículos en revistas especializadas y otras colaboraciones de tipo académico, destacando sus trabajos en fenomenología de la corporalidad. 
y el orden de lo eterno, el de lo limitado y el de lo infinito, el de profano y el de lo sagrado. La mediadora entre ambos órdenes es Babette, que asume una función genuinamente sacerdotal. Sin embargo, por una paradójica inversión, lo que parece profano y mundano, viene al rescate de lo que se tiene por espiritual y sagrado.

Palabras clave: BANQUETE; RECONCILIACIÓN; SAGRADO; PROFANO; CUERPO; ALMA

Our work on the banquet as a feast of reconciliation takes the form of a comment on the film Babette's Feast, ${ }^{2}$ by Gabriel Axel, a faithful rendition of the story of the same name by Isak Dinesen, the pseudonym of Karen Blixen. ${ }^{3}$ From the very outset the story is set in an atmosphere of tales and legend, and although everything happens in a specific time and place - that is, around 1885, in the village of Berlevaag in a fjord in Norway - one could say that the story is one from the timeless dimension of the great archetypes: what is recounted might very well be, more profoundly, our own history.

\section{I}

It is the centenary of the birth of the Dean, a charismatic Lutheran pastor who had gathered around him a small community of devoted disciples. His two daughters, Martine and Philippa, both single and dedicated to serving the poor and the elderly in a congregation which, despite all their efforts, is showing clear signs of decline, decide to offer a simple commemorative dinner in memory of their father, now deceased. However, Babette, a French maid who had arrived in the small village twelve years before from Paris, in a desperate flight from bloody political repression, offers to prepare for them all "a French dinner, a real French dinner" out of her own funds, which have increased suddenly by a stroke of good fortune.

What was to have been a frugal repast accompanied by some pious hymns becomes a lush banquet of great exquisiteness and refinement; the meeting of a group of embittered elderly and infirm individuals, gripped by rancorous memories and cruel remorse, is transformed into a fraternal

[2] Babettes Gaestebud (Babette's Feast), a Danish film released in 1987, directed by Gabriel Axel and featuring Stéphane Audran, Jean-Philippe Lafont, Gudmar Wivesson, Jarl Kulle, Brigitte Federspiel, Lisbeth Movin, Bodil Kjer, and Bibi Anderson. The cinematography was by Henning Kristiansen and the music by Per Norgaard. It received the 1987 Academy Award for the Best Foreign Language Film.

[3] The story "Babette's Feast" is from a collection of short stories entitled 'Skeebne-Anekdoter' (Anecdotes of Destiny). I will quote in the text fragments of the story, as if they were fragments of the script, as it is a film adaptation that was very faithful to the text and spirit of the original story. To do this I have made use of the following edition: Dinesen, Isak, Anecdotes of Destiny. London: Penguin Books, 1988.

[4] Dinesen, Isak, Anecdotes of Destiny, p. 42. 
agape, with the warmth of transfigured faces and shining eyes. From the conspiratorial whispers and reproaches in a low voice, we turn to the inspired words and poetry welling sincerely from the heart; what was feared as a demonic coven becomes a reflection of a heavenly banquet which would delight the angels. As at the wedding in Cana, the insipid water is unexpectedly transformed into the best of wines. That wine, as Béla Hamvas says, "brings back our original life, Paradise, and shows us where we will meet in the last universal celebration." ${ }^{5}$

The evangelical comparison, is, in fact, not an idle one. There are twelve guests gathered at the table, as at the Last Supper. The magnificent cook, Babette, devotes all her energies and all of her money (ten thousand francs received from a lottery prize) to this unique evening in which she ends up exhausted and penniless, thus making clear the sacrificial aspect of the banquet. The exceptional artist - to whom the puritan ladies had given shelter without knowing that she had been the "greatest culinary genius of her time" - is capable of transforming the profane (bread, wine, quail, turtle, fruit) into a sacred food, whose effect transfigures and spiritually elevates the guests: "The convives grew lighter in weight and lighter of heart the more they ate and drank." ${ }^{6}$ Here the paradox lies in the fact that spiritual elevation does not occur through rejecting the material, denying the senses, or fleeing from pleasure, as those saintly villagers had always believed. Rather the opposite is true: through the artistically elaborated material the senses are awakened for the first time to a type of experience where the corporeal and the spiritual are no longer at odds with each other and in which, to the surprise of the elderly puritans, the tastier a bite is, the more sublime and pure are the thoughts and desires that accompany it. Babette was able to convert a dinner - having been the chef of the Café Anglais earlier in her life, and also on that unrepeatable night in Berlevaag - "into a love affair of the noble and romantic category order in which one no longer distinguishes between bodily and spiritual appetite or satiety!." "Freed from the scruples of a parched and empty spiritualism, the guests at the celebration rediscover in the material, transformed into work of art, an epiphany of the divine.

Although the prodigious feast has its regenerative effect on all the diners, only the general Lorens Loewenhielm, who is, so to speak, from the outside world - and who had rubbed shoulders in his social circle with the

[5] Hamvas, Béla, La filosofia del vino. Barcelona: Ed. Acantilado, 2014, p. 38.

[6] Dinesen, Isak, op. cit., p. 57-58.

[7] Ibid., p. 58. 
aristocrats who frequented the Café Anglais - is aware of the true nature and exquisiteness beyond measure of what is being raised to their mouths. More than thirty years before he had attended gatherings organised by the Dean, but remained silent, not having known what to say to a glass of water and some simple biscuits. However, on this extraordinary occasion of the banquet, without setting aside his perplexity and bewilderment, and as if he were living a miracle, he stands up, speaks solemnly and gives an inspired speech which is the central thread of the whole story. It begins thus: 'Man, my friends,' said General Loewenhielm, 'is frail and foolish. We have all of us been told that grace is to be found in the universe. But in our human foolishness and short-sightedness we imagine divine grace to be finite. For that reason we tremble..."

\section{II}

General Loewenhielm goes to the celebration in memory of the late Dean in a particular state of mind. For him, it is not just another meeting. During the dinner, which he imagines will be mediocre and dull, he has to discover whether the decision he had made thirty years ago was the correct one. As he recognises at one moment of his speech, "We tremble before making our choice in life, and after having made it again tremble in fear of having chosen wrong." (60) In that already distant past, as a young cavalry lieutenant, he had been forced by his father, who had hoped to see him change his behaviour, to spend some time on the desolate coast of Jutland in the mansion of his aunt. And there he had been captivated by the almost unearthly beauty of Martine, one of the two daughters of the Dean, whom he had met by chance when he was out riding his horse. However, despite feeling captivated by her angelic face, he opts, after a bitter internal debate, to stay away from her for evermore, that is, from the life of simplicity and spiritual elevation that a future in her company would bring. "I'm going away forever!' he cried. 'I shall never, never see you again! For I have learned here that Fate is hard, and that in this world there are things which are impossible!"10

The young lieutenant opts for a life of military successes, of splendour at court, of luxury, ostentation and fame - quite the contrary to that "purer and higher" existence he had glimpsed in the face of Martine. And after all the time that has gone by, since Martine and Loewenhielm parted, up until their reuniting, the soldier has largely achieved everything he had

[8] Ibid., p. 60.

[9] Idem.

[10] Ibid., p. 27. 
proposed for himself in this worldly life. However, it raises the question of whether a life of continued and celebrated successes might or might not actually be a complete failure. What point is there for the general - one might say in allusion to the well-known verse - to have gained the whole world, if in the end he feels he has lost his soul? (Cf. Mt 16, 26)

The superabundant feast, where only a small meal had been expected, and the reencounter - despite the many intervening years - with the glowing face of Martine ("But how serene was the forehead, how quietly trustful the eyes..."11) resolved the doubt of the beleaguered General in an unexpected manner. In a moment of profound illumination, which coincides with the delivery of the speech, he gets to see that what he had renounced, afraid and convinced that he had lost it forever, is returned to him against all expectation, because while human beings debate options which appear to be antagonistic and incompatible, grace is infinite, and for God nothing is impossible: "See! That which we have chosen is given us, and that which we have refused is, also and at the same time, granted us." ${ }^{12}$

It is hard not to see in the different personalities of the characters, in the almost mystical resolutions and in the many paradoxes of Babette's Feast, a Kierkegaardian ${ }^{13}$ resonance that permeates and pervades the atmosphere of the whole story. The biblical figure of Abraham that we see dramatically described in his 'Panegyric Upon Abraham - Fear and Trembling' who makes "the movement of infinite resignation" in preparing to sacrifice his son Isaac, but recovers him against all logic thanks to the "movement of faith", ${ }^{14}$ reminds us of General Loewenhielm discovering, in a kind of inner revelation, the infinity of grace and the paradox of "that which we have rejected is poured upon us abundantly." 15

Also the young Lieutenant Loewenhielm - although his decision appears to go in a diametrically opposite direction to the sacrificial attitude of Abraham - performs a painful act of resignation, rejecting for good the possibility of a shared life with Martine, despairing of his ability to settle in the religious sphere of existence and abandoning himself - we might say once again using Kierkegaardian terminology - to an aesthetic life, one of honours, pleasures and riches. However, the depth of love experienced by

[11] Ibid., p. 55.

[12] Ibid., p. 60.

[13] The imprint of the thought and life of the Danish philosopher in the narrative of Blixen is highlighted in the following article: Jean Schuler, "Kierkegaard at Babette's Feast: the Return to the Finite", Journal of Religion and Film, vol I, n 2 (1997).

[14] Kierkegaard, Sören, Temor y temblor (Trad. Vicente Simón Merchán). Madrid: Ed. Tecnos, 1987, p. 98.

[15] Dinesen, Isak, op. cit., p. 60. 
the young man cannot be uprooted from inside him, and despite his efforts to forget ("So he pulled himself together, and in the greatest effort of his young life made up his mind to forget what had happened to him in Berlevaag." $\left.{ }^{16}\right)$, the face of the eldest daughter of the Dean follows him constantly whenever he goes.

The infinite nature of this renunciation is evidenced by the countless occasions when Loewenhielm has to struggle with the memory of his beloved and the desperate conviction that he will never recover what has been abandoned. However, just as the biblical story of Abraham ends with an unexpected twist, as the patriarch regains Isaac when he had renounced him, likewise general Loewenhielm reconnects unexpectedly with the object of his forsaking, whom he thought he had left behind irredeemably: "I have been with you every day of my life. You know, do you not, that it has been so?" (...) "And, he continued, I shall be with you every day that is left to me. (...) For tonight I have learned, dear sister, that in this world anything is possible." ${ }^{\prime 17}$

\section{III}

In addition to the figure of the general, other characters in Babette's Feast are also marked by resignation and by the effort of a final renouncement. Famed opera singer Achille Papin, who came from Paris to Norway, is the second of the knights from the outside world whose heart is troubled by the beauty of one of the two daughters of the Dean. In this case it is Philippa, the daughter who is a year younger, whose extraordinary voice is what he first admires, having heard her singing in church. "Almighty God,' he thought, 'Thy power is without end, and Thy mercy reacheth unto the clouds! And here is a prima donna of the opera who will lay Paris at her feet." 18 The celebrated singer, completely enraptured, obtains the Dean's permission to give the young lady singing lessons and he discovers with increasing surprise the great talent of the unknown soprano, an artistic talent with the capability of bringing joy to emperors, princesses, ladies, bels esprits, and also the common people and the oppressed. However, on this occasion it is Philippa with her promising voice, who, without explanation, gives up a brilliant future as a celebrated diva in the main theatres of Europe, and also a possible love affair with Papin. In the case of Philippa the resignation lies in the aesthetic dimension of existence, in

[16] Ibid., p. 27-28.

[17] Ibid., p. 62.

[18] Ibid., p. 29. 
favour of a life of dedication and selflessness continuing the work of her father, the Dean.

Finally, Babette, the powerful centre of the whole scene, is also a character profoundly marked by resignation and sacrifice. This is not just because she has lost her husband and her son, the victims of a bloody political repression, but also because when she flees she leaves behind the only city and the only social context in which her exquisite culinary art could be sustained and make sense. Paradoxically, her archenemies, the general Gallifet and the bombastic list of aristocrats whom she would like to see dead, are the only individuals who - like the general Loewenhielm might appreciate the value of her art. Moreover, when she finally has the financial means to return to her homeland, she spends everything she has, down to the last penny, to hold this memorial feast for a group of people nearly all of whom are quite unaware of the value of what they are eating or savouring, and are doing so almost through obligation. The presence of General Loewenhielm at dinner is also a paradoxical and unexpected recovery of something - the recognition of her genius, something that Babette would have given up forever, "But as a new dish was served he was silenced. 'Incredible' he told himself. 'It is Blinis Demidoff!' He looked round at his fellow-dinners. They were all quietly eating their Blinis Demidoff, without any sign of either surprise or approval, as if they had been doing so every day for thirty years." ${ }^{19}$

The invitation to the meal for twelve people to commemorate the centenary of the birth of the late Dean, a meal in which Babette has invested all the money that would have allowed her to start a new life away from the austerity of the village in the forgotten fjord, suggests a great sacrifice on the part of the cook and an act of generosity almost without limit. However, the brilliant artist responds with enigmatic words to the bewildered gesture of thanks from the two sisters, "'Dear Babette,' she said softly, 'you ought not to have given away all you had for our sake.'(...) 'For your sake?' she replied. 'No. For my own. (...) I am a great artist!' she said.” 20

These words of Babette bring into focus the question of artistic genius and the possibilities - thwarthed for Babette in various ways, but also for Philippa - of developing one's talents in this life. Indeed, a subtle thread unites the two female characters, because each one, whether it be in cuisine or in singing, is a great artist, which enables them to infuse the most diverse of people with happiness through their art: "I could make them happy [Babette recognizes]. When I did my very best I could make them perfectly

[19] Ibid., p. 56.

[20] Ibid., p. 66. 
happy." ${ }^{21}$ But each has had to give up her talent in one way or another, as if their creative talents could not be reflected in this life because of the constraints of finitude. The old Achille Papin, who wrote to the beautiful sisters he had known in his youth to ask them to show their generosity and take in the fugitive Babette who knocks half-dead on the door of their house in Berlevaag, adds in his letter a few words to Philippa, where he expresses the hope that from the impossibility of realising her talent in this life it may be extended beyond death: "As I write this, I feel that the grave is not the end. In Paradise I shall hear your voice again. There you will sing, without fears or scruples, as God meant you to sing. There you will be the great artist that God meant you to be. Ah! how you will enchant the angels." 22

And these are the same words that years later Philippa says to Babette - and they conclude the narration - about the material impossibility, that is to say, earthly or finite, of once again recreating her work of art: "Yet this is not the end! I feel, Babette, that this is not the end. In Paradise you will be the great artist that God meant you to be. Ah!' she added, the tears streaming down her cheeks. 'Ah, how you will enchant the angels!'”23

\section{IV}

The feast organized by Babette takes place in the context of indescribable renunciations and unexpected reencounters. Meanwhile, the great cook has arranged the dinner methodically, leaving not the slightest thing to chance. It is not a conventional meal. She has defined it as a "French dinner, a real French dinner." Accordingly, it is a type of agape subject to strict rules of composition, a choreography planned down to the last detail. To begin with, the ingredients of the food and everything involved in it, i.e., linen, cutlery, crockery, glass, etc., come from France. "Table linen and plate had been magically mangled and polished, glasses and decanters brought, Babette only knew from where." ${ }^{44}$ Everything in the film, and hence, in the narration, that brings a breath of fresh air to the spirit of those villagers, comes from outside. From the outside world arrive successively Lorens Loewenhielm and Achille Papin, from the outside world Babette comes too, and from the outside there come, by boat and finally in a small ship, strange dinner ingredients that are regarded with suspicion by the villagers who are quite unprepared to face any kind of novelty with

[21] Ibid., p. 68.

[22] Ibid., p. 34.

[23] Ibid., p. 68.

[24] Ibid., p. 48. 
serenity. They are ingredients selected with care, there is a mise en scène in which nothing is overlooked, from the perfectly pressed table linen, the succession of glasses of different sizes as if they were sacred vessels- and in a very special way, the selection of wines. "What is there in this bottle, Babette?' she asked in a low voice. 'Not wine?' 'Wine, Madame!' Babette answered. 'No, Madame. It is a Clos Vougeot 1846!' After a moment she added: 'From Philippe, in Rue Montorgueil!"' 25

The studied succession of the drinks throughout the banquet, perfectly complemented with the dishes served, keeps to a strict order whose secret is known only to the one who, we might say, has directed and officiated at the ceremony. The seriousness and the transcendence of each of the sensitive elements (light, colour, texture, flavour, aroma, etc.) hark back to a liturgy or a religious ritual, in which actions are performed in accordance with arrangements and practices established in ancient times. ${ }^{26}$ The immemorial structure which is repeated, thanks to the template of a liturgy and its ritual acts, is what makes up "a real French dinner" and in the context of Babette's Feast it signifies something altogether transcendental and transformative.

If, as Béla Hamvas says, food corresponds to the physical aspect, while drink (that is to say, preferably wine) constitutes the spiritual aspect of any agape,${ }^{27}$ then the perfect marriage of one and the other, in which the interlocking elements do not cancel each other out but rather mutually reinforce and enhance the flavour, bring to mind the union of body and soul, which is both necessary and precarious at the same time. This is, basically, the true nature of the feast. Apparently we are led to believe that this is a feast celebrating the centenary of the Dean, and this is what Martina, Philippa, the general and each one of the diners think. But in reality - and that is Babette's hidden culinary secret - it is a feast in which reconciliation with oneself is celebrated and and effectively achieved, the recovery of a lost unity between body and soul, between matter and spirit. From that first step in which the fundamental internal fragmentation is overcome, there occur, in a chain sequence, so to speak, the other levels of unity, which are also fragmented and disconnected - unity with others, with the cosmos, with God.

As in any religious situation we have here an encounter between two orders that seem incommensurable: the temporal order and the order of the eternal, the limited and the infinite, the profane and the sacred. The

[25] Ibid., p. 45.

[26] Cf. Duch, Lluís, Antropología de la religión. Barcelona: Ed. Herder, 2001, p. 183.

[27] Béla Hamvas, La filosofía del vino, p. 79. 
mediator between the two orders is Babette, who takes on a genuinely priestly role. However, by a paradoxical reversal, that which seems profane and mundane comes to the rescue of that which is held to be spiritual and sacred. Salvation comes from outside and causes the spirit lurking in the hidden interior to emerge; the senses, the food and the drink rally to the rescue of the spirit languishing in its recalcitrant autophagia.

In Babette's Feast nature and grace, and time and eternity, reunite and embrace each other: "Taciturn old people received the gift of tongues; ears that for years had been almost deaf were opened to it. Time itself had merged into eternity." ${ }^{28}$ For this reason the hymn that is repeated over and over again like a leitmotif is a verse which has its inspiration in the eighty-fifth Psalm: "Mercy and truth, my friends, have met together ... Righteousness and bliss shall kiss one another". ${ }^{29}$ In other words, the soul has kissed the body, rather than viewing it with repugnance, and the body has poured its warmth and vitality into the soul, rather than fearing it or hiding from its presence. From this fundamental unity links are reforged, and the goodness of creation is rediscovered; we feel at home in the cosmos, the snow falls, and the bond between all things is reestablished: "The guests from the yellow house wavered on their feet, staggered, sat down abruptly or fell forward on their knees and hands and were covered with snow, as if they had indeed had their sins washed white as wool, and in this regained innocent attire were gambolling like little lambs." 30

The fundamental conclusion of Babette's Feast is the reconciliation of the soul and the body, of nature and grace, of time and eternity, which embrace and kiss each other. And that state is undoubtedly a return to the situation of original innocence in which none of the fundamental bonds - with themselves, with other human beings, with the cosmos, with God - was damaged or broken; it is a recovery of life in its primordial beauty and integrity. Thus, the unwary diners at the feast "realized that the infinite grace of which General Loewenhielm had spoken had been allotted to them... they had seen the universe as it really is. They had been given one hour of the millennium." 31

[28] Dinesen, Isak, op. cit., p. 61.

[29] Ibid., p. 59.

[30] Ibid., p. 63.

[31] Ibid., p. 62. 